\title{
Research on the Stereoscopic Hybrid Teaching Mode of Histology and Embryology against the Background of Information
}

\author{
Shi-Min \\ Medical College \\ Xi'an Peihua university \\ Xi'an, China \\ 1243838277@qq.com
}

\author{
Ma-Simin \\ Health Science Center \\ Xi'an Jiaotong university \\ Xi'an, China
}

\begin{abstract}
In order to evaluate the effect of the stereoscopic hybrid teaching mode of "the integration of theory, experiment and network teaching" in the teaching of Histology \& Embryology (HE), we selected the students of class 1-3 freshmen (enrollment in 2017) (test group) of clinical medicine major. Based on the network teaching platform, we created a teaching resource library, and adopted a stereoscopic hybrid teaching mode and compared with the academic scores of students class 4-7(control group) using traditional teaching mode, then conducted a questionnaire survey on the test group. Our results show that average scores of theoretical courses and experimental courses, the excellent rate and the pass rate of the test group were higher than the control group, and the survey results show that $99.2 \%(123$ students) are satisfied with the new teaching mode. Our finding indicates that the new teaching mode is widely accepted by students and has good feasibility. It can improve students' interest, cultivate their ability of active learning, and lay the foundation for medical education of applied talents.
\end{abstract}

Keywords-Teaching reform; The integration of theory; Experiment; Network teaching; Informatization; Histology \& Embryology

\section{INTRODUCTION}

Histology \& Embryology(HE) is one of the main courses in medical basics, focusing on the microstructure and related functions of human organ tissues. It is closely related to physiology, pathology and clinical courses, and is a strong cornerstone for medical students to enter clinical work in the future. Given the HE science's characteristics that teaching contents is numerous, abstract and difficult to understand, and the "spoon-fed" teaching methods in the past, resulting in students' interest is not strong. Furthermore, our school is a local undergraduate college that aims to cultivate practical talents. Therefore, the HE in clinical medicine is compressed to 48 hours. The traditional face-to-face teaching method can not complete the teaching task with high quality and quantity.

Outline of National Medium- and Long-Term Education Reform and Development Plan(2012-2020) is clearly proposed: "Information technology has a revolutionary impact on the development of education. It must be highly valued. Incorporate information into the overall educational strategy, deploy educational information networks ahead of time, and promote the modernization of educational content and teaching methods." Under the background of informatization, the traditional class-teaching mode with long time and large capacity can not meet the individualized learning needs of students, and MOOC has been widely used in colleges or universities. Therefore, the convenient informationization has made teaching reform imminent. Up to now, the international education community has reached a consensus that only the combination of traditional learning with networked learning can achieve the best learning outcomes [1]. Therefore, Only by changing the concept of teaching, integrating online teaching with classroom teaching, and making teaching resources digital and shared, can we realize the networking of teaching resources, the modernization of teaching methods, and serves the purpose of cultivating practical talents [2]. As a exquisite courses and a school-level key education reform project, by using networked teaching methods to serve students, it is beneficial to improve teaching outcomes.

\section{OBJECTS AND METHODS}

\section{A. Research objects}

We selected the 124 students of class 1-3 freshmen (enrollment in 2017, clinical medicine major) as the research objects(test group) of the new teaching mode. 156 students of class 4-7 of same major using traditional teaching mode without network teaching platform as reference(control group).

\section{B. Methods}

1) Integrate teaching resources and establish the "integration of theory and experiment" teaching mode

The guiding ideology of "integration of theory and experiment" teaching mode is to break the boundaries between theoretical, experimental and practical courses, and integrate theoretical teaching with practical teaching[3]. This allows students to reduce a thinking step in the learning process, not only can enhance students' understanding of the human body structure intuitive feeling, but also quickly establish the layering and three-dimensional sense of the human body structure, facilitate the understanding of the details of the class book, and improve the effectiveness of memory[4]. The new teaching mode can meet the teaching needs. It not only ensures systematic learning for knowledge, but also changes the boring 
current situation of the atmosphere in theoretical class. It integrates the guidelines for the training of talents in our college, follows the cognitive rules, and finds the connection points of every chapter. After investigated for the clinical and nursing students, we integrated the basic knowledge points, clinical knowledge points and scientific knowledge points into HE class, and planned the teaching content as a whole. The teaching content line of HE is: Human embryogenesis $\rightarrow$ Four types of tissues $\rightarrow$ Tissue structure, function, genesis and malformation of various organ systems.

2) Design teaching resource library, enable the access of information technology teaching network platform

Starting from the cultivation of students' self-learning ability, we refer to domestic and foreign medical teaching websites, collected teaching materials according to teaching goals, extended the teaching visualfield, carefully designed the teaching content of each class, and established a perfect network platform of teaching resource library. Each chapter in the resource library is subdivided into four modules: pre-class study, course introduction, in-class learning, and review. The teaching resource library includes the basic teaching resource (class starting instructions, teaching plan, syllabus, PPT courseware and micro-course video), case analysis and discussion, exercises and tests in each chapter. The steps are: meeting to determine the video lecture form $\rightarrow$ teacher prepared questions (writing scripts, courseware, exercises, case analysis) $\rightarrow$ recording video (about 10 minutes of difficult points explaining) $\rightarrow$ interspersed with interactive classwork in the video $\rightarrow$ each chapter test $\rightarrow$ platform maintenance and student feedback.

3) Taking students as the main body, establishing a stereoscopic hybrid teaching mode, and integrating theory, experiment and network teaching

The stable and reliable network and micro-morphology digital interactive system ensured the smooth implementation of this model. The new teaching mode that integrated class, experiment and network teaching has improved the teaching effect and teaching quality. The network teaching resource library is rich. it is not subject to time and space restrictions, and becomes the most effective auxiliary teaching method for class-teaching[5-6]. Although the advantages of online teaching are numerous, if the virtual teaching environment is not effectively guided by teachers, it will weaken the learning effect of students and it is difficult to cultivate their independent learning ability. Therefore, the combination of class-teaching with online-teaching, in-class and extra-class supplements, it can play their respective advantages. Based on the online course platform, they can provide strong support for students' independent learning in terms of resources, time and learning methods. Through the network teaching to achieve the student-centered, teacher-led teaching philosophy.

\section{Teaching process of stereoscopic hybrid teaching mode}

\section{1) Before class}

Teachers publish learning requirements on the network platform, upload learning conduction, teaching videos, and mark out the key points. Students complete their initial learning and homework within the specified time, conduct individual studies and group discussions, and prepare group reports(face-to-face) in class. The teacher's role is a guider and interpreter. They observe the student's learning situation and answer the questions on the platform. The student's role is the active learner.

\section{2) In class}

Firstly, in the face-to-face class, the teacher mainly sorts out the key content, summarizes and analyzes the problems so that students can systematically learn related theories, methods and techniques. Then students ask the questions, and then get explanation by group discussion or by the instructor. Subsequently, the teacher gives out the learning task, and let the students use the knowledge of the pre-class study and the so-called difficult point that the teacher explained to complete. Achieve changes in teaching models and the organic combination of theory and practice. Secondly, on the network teaching platform, the content of HE course can be divided into three modules. That is learning, practicing and doing. "Learning" is learning the basic concept of HE, "practicing" means strengthening knowledge points through clinical case analysis, "doing" means strengthening practice through cooperative learning. Through teaching videos, courseware, micro-courses and other resources or web search, students learn independently, complete and submit homework, take the tests, and be evaluated timely by teachers.

\section{3) After class}

The teacher arranges homework, conducts tests, and collects student feedback and suggestion through the network platform. Teachers can submit their learning outcomes on the platform as evaluation materials, or even convert them into part of the curriculum resources to show.

\section{4) Questionnaire}

In the implementation of the 2017 teaching reform of clinical medicine students, We designed and compiled "Questionnaire on the satisfaction of the stereoscopic hybrid teaching of $H E$ ", and conducted a questionnaire survey, in order to provide feedback on the effectiveness of this teaching reform. Objective entries are as follows: cultivation of autonomous learning ability, access to knowledge, understanding and memory of knowledge, increased interest in learning, interaction between teachers and students, and satisfaction with the stereoscopic hybrid teaching mode.

\section{RESULTS}

\section{A. Evaluation of test scores}

The test scores consist of two parts: the theoretical class and the experimental class. The theoretical score accounts for $60 \%$ and the experimental scores account for $40 \%$. Through the comparison of the average scores of the theoretical class, the experimental class, the excellent rate and the pass rate. It is found that by using the stereoscopic hybrid teaching mode, the students of Class 1-3 (test group) of the 2017 clinical medicine major are better than the students of class 4-7 of the major. It had significant difference between the two groups $(P<0.01)$, but there was no significant difference of the pass rate between the two groups.(Table I) 
TABLE I. COMPARING AVERAGE SCORE OF THEORETICAL CLASS, EXPERIMENTAL CLASS, EXCELLENT RATE AND PASS RATE BETWEEN THE TWO GROUPS OF STUDENTS

\begin{tabular}{|l|c|c|c|c|}
\hline Groups & $\begin{array}{c}\text { average score } \\
\text { of theoretical } \\
\text { class }\end{array}$ & $\begin{array}{c}\text { average score of } \\
\text { experimental } \\
\text { class }\end{array}$ & $\begin{array}{c}\text { excellent } \\
\text { rate }\end{array}$ & $\begin{array}{c}\text { pass } \\
\text { rate }\end{array}$ \\
\hline Test group & $86.3 *$ & $89.1 *$ & $34.5 \% *$ & $96.2 \%$ \\
\hline $\begin{array}{l}\text { Control } \\
\text { group }\end{array}$ & 72.6 & 75.4 & $23.1 \%$ & $89.7 \%$ \\
\hline
\end{tabular}

* The two groups $P<0.01$

\section{B. The effectiveness in class}

By using the stereoscopic hybrid teaching mode, the effectiveness in class has been significantly improved. Firstly, the network platform has a more frequently click rate, the atmosphere in class is more active, the enthusiasm and initiative of students are significantly increased. They are more proactive in asking questions, and using the knowledge they have learned to solve problems. Secondly, students can take the initiative to analyze, generalize, summarize and complete homework. From the analysis of homeworks, students can grasp the knowledge points more accurately and meet the class-teaching requirements. In addition, in the case-answering and discussion interaction, students learn to access the literature and independently learn clinical disease-related content. It stimulates students' interest in learning, promotes the cultivation of their scientific thinking and clinical skills, and subsequently achieves good teaching outcomes.

\section{Questionnaire results}

By collecting the questionnaire, we obtained the positive feedback on the teaching model. The results of the survey are shown in Table II.

TABLE II. THE ITEM OF QUESTIONNAIRE AND ITS’ RESULTS

\begin{tabular}{|l|l|l|}
\hline \multicolumn{1}{|c|}{ Item } & \multicolumn{1}{|c|}{ Good } & \multicolumn{1}{|c|}{ Invalid } \\
\hline Cultivation of autonomous learning ability & $101(81.5 \%)$ & $16(12.9 \%)$ \\
\hline Access to knowledge & $105(84.7 \%)$ & $12(9.7 \%)$ \\
\hline Understanding and memory of knowledge & $112(90.3 \%)$ & $9(7.3 \%)$ \\
\hline Increased interest in learning & $115(92.7 \%)$ & $7(5.6 \%)$ \\
\hline Interaction between teachers and students & $103(83.1 \%)$ & $3(2.4 \%)$ \\
\hline Satisfaction with the stereoscopic hybrid teaching mode & $114(91.9 \%)$ & $2(1.7 \%)$ \\
\hline
\end{tabular}

\section{DISCUSSION}

$\mathrm{HE}$ is a micromorphology course, which is characterized by "invisible, intangible". If traditional teaching mode is used, the teaching effect is poor and it can discourage students' enthusiasm for learning. Starting from the basic medical curriculum, relying on the networked teaching platform, integrating the old and new teaching resources, constructing the teaching resource library, realizing the sharing of the teaching resources of the $\mathrm{HE}$, we established a stereoscopic hybrid teaching mode which can provide students with an independent and convenient knowledge acquisition platform, giving full play to the student learning role. It helps to establish a solid frame of HE knowledge.

\section{A. Expand the space of medical education and continued the class-teaching time}

According to the needs of college applied curriculum reform, it is imperative to compress compulsory courses, reduce theoretical classes, and increase practical teaching[7]. However, the advancement of the discipline requires an ever-increasing content of teaching, and how to ensure that students receive sufficient knowledge in the context of compressed class-hours, which requires teachers to use extracurricular teaching time by other ways. The teaching resources such as courseware, teaching videos, and study guidance on the network teaching platform have become the extracurricular instructors. They are not subject to time and space restrictions and have become the most effective auxiliary teaching method for class-teaching. We use information technology to combine traditional teaching with online teaching, and build a stereoscopic feature teaching platform integrating theory, experiment and network teaching, which makes the course present diverse teaching resources. It makes up for the limitations of time and space in traditional classroom teaching, and extends the classroom, providing students with a more convenient and free learning environment. Our results show that $94.3 \%$ of the students believe the new teaching platform is rich in teaching resources, can expand viewfields, cultivate clinical thinking and skills more easily, and improve students' learning ability more effectively.

\section{B. Realize resource integration, deepen understanding and memory of knowledge and improve teaching effectiveness}

The combination of theory, experiment and network teaching, the stereoscopic hybrid teaching mode of HE realizes the integration and sharing of new and old teaching resources, and promotes the formation of a relatively complete networked teaching resource library and teaching system. This teaching mode not only promotes the advantages of traditional resources, but also enhances the application value of teaching resources by means of information teaching. According to the teaching needs, it ensures that the teaching resources library complement and support each other, and promotes the absorption and application of the knowledge of HE. In the specific practice, the stereoscopic hybrid teaching mode firstly overcomes the obstacles of the disconnection and repetition of traditional teaching theory and experiment. Subsequently, we specifically integrate the information design and teaching content of the teaching resource library after investigation, and discuss the teaching materials, and recruit teachers of the basic course and the professional class to prepare lessons, and then the optimized cases were integrated into the teaching content. Therefore, the integration of teaching resources is based on reality, and grasps the knowledge contact points with other disciplines, realizes the integration of knowledge, and forms a 
rich library of teaching resources. We set up the network platform to realize a stereoscopic integration of teaching resources, and apply it to specific class-teaching, ensure the repetition and enhancement of each knowledge point, and optimize the teaching effect. Our results show that $97.6 \%$ (121) students think that the new mode helps the knowledge understanding and memory, and $99.2 \%$ (123 people) are satisfied with the stereoscopic hybrid teaching mode.

\section{Combine network teaching and multiple ways to improve students' self-learning ability}

$\mathrm{HE}$, which is viewed invisible and intangible course, is an abstract micromorphology. The traditional teaching mode leads to poor teaching effect and students' enthusiasm for learning is not high[8]. The stereoscopic teaching platform can achieve maximum resource optimization. Firstly, through the basic course and professional class teachers to prepare lessons achieved the integration of teaching content. Synchronization of theoretical and experimental contents, allowing students to have an intuitive understanding of abstract knowledge points. Furthermore, the network teaching platform is rich in learning resources, expands the educational space, and assures students' independent learning. However, in this virtual teaching environment, if there is no teacher intervention and guidance, it will inevitably weaken the students' learning effect, and is not conducive to the comprehensive ability cultivation of students' self-learning ability and case analysis ability. Therefore, in the process of students' self-learning, teachers should guide students in multiple ways. The new teaching mode, which adopts book and network guidance, network course learning and classroom face-to-face combination, case analysis and interaction, online homework or self-testing and other diversified methods. Throughout the course of the lecture, the teacher sets questions, guides gradual and discusses interactively, and then conducts microscopic observation and network testing, allowing students to learn from knowledge to analyze problems, from morphological observation to problem discussion, from knowledge of the subject to related subject knowledge, all aspects are trained and exercised. The results showed that $94.4 \%$ (117) of the students were trained in their own learning ability through this teaching mode.

\section{Strengthen the interaction between teachers and students and improve students' interest in learning}

The teacher-led traditional teaching model can not adapt well to the learning style under the background of the information era, and should make full use of new technologies to change the situation. Young people like to play with mobile phones, often do not leave their hands. The construction and use of the stereoscopic teaching mode realizes the online and offline hybrid teaching, providing a simulated learning environment for the interaction and communication between teachers and students. It eliminates the tension between students and teachers face-to-face, and promotes the interaction between teachers and students from multi-dimension. In particular, It has changed the situation that some students did not dare to ask questions in the past, so that students can boldly question and fully express their opinions. The online teaching platform has designed case analysis and discussion to motivate students to actively think and actively participate in Q\&A, thus stimulating students' interest and quality of learning. It shows that $93.5 \%$ (116) of the students believed that through the design of the Q\&A library, the communication between teachers and students was further enhanced, and the classroom atmosphere was activated. 98.4\% (122) of the students think their interest in learning has improved.

In short, the stereoscopic hybrid teaching mode, integrating of the theory, experiment, and network teaching, brings a revolution to the teaching of $\mathrm{HE}$, realizes the education mode from "teaching-based" to "learning-oriented", and meets the needs of students' individualized learning. The new teaching mode of HE combines network teaching with traditional teaching reasonably, breaks the time and space constraints of teaching resource, maximizes knowledge points, promotes optimized teaching resources for students, and trains students to learning, thinking and good habits[8]. In the specific class teaching, we adopted heuristic, discussional, exploratory and other teaching methods to cultivate students' independent learning ability, which can greatly improve the students' enthusiasm for learning. Therefore, the stereoscopic hybrid teaching mode of the HE has the ability to teach the theoretical foundation, learn the ability to propose, analyze and solve problems, strengthen the awareness of independent learning, and enrich the teaching resource library. However, the online course needs to improve the information level of teachers in practice, further supplement and improve the teaching resource library, give full play to the respective advantages of network teaching and traditional teaching, make the online course effectively promote the improvement of teaching quality, and promote the cultivation of practical talents.

\section{REFERENCES}

[1] Wang Yuan. Research on the mixed teaching effect of "Health Assessment" based on moodle platform [D]. Southern Medical University, 2017.

[2] Zhang Jia-Lu, Wang Xiao-Ping. Research on the reform of college course teaching method based on cloud space[J]. The Chinese Journal of Ict in Education, 2015, 12: 73-76.

[3] Li Xiao-Lei, Chen Yu-Hong, Fang Ming-Ming, et al. Application evaluation of theory and practice integration teaching mode in the co-building course surgical nursing [J]. Chinese Clinical Nursing,2016, 8(1) : 67-70.

[4] Yuan Heng, Wu Chang-Chu, Liu Guan-Lan, et al. Applied Research of "Integration of Theory and Practice" Teaching Mode in the Histology and Embryology Experiment Teaching [D]. The Guide of Science \& Education,2017,7: 125-127.

[5] Loftus J, Stavraky T, Urquhart BL. Design it yourself (DIY): in-house instructional design for online pharmacology[J]. Adv Health Sci Educ Theory Pract, 2014, 19(5): 645-659.

[6] Lahti M, Htnen H, Vlimki M. Impact of e-learning on nurses' and student nurses knowledge, skills, and satisfaction: a systematic review and meta-analysis[J]. Int J Nurs Stud, 2014, 51(1): 136-149.

[7] Paulsen FP, Eichhorn M, Bruer L. Virtual microscopy the future of teaching histology in the medical curriculum [J]. Ann Anat, 2010, 192(6): 378-382.

[8] Yang Li, Zhao Min, Zhang Dong-Kui, et al. Construction and practice of network course of Histology and Embryology[J]. Medical Information, 2018, 31(2): 13-15 